\title{
多孔質アクリル繊維中に不規則に発達した孔の形態観察
}

\author{
日本エクスラン工業侏 川崎 史郎，芦田 \\ 岡山大学工学部釙口知子, 島村

\section{Transmission Electron Microscopy of Pores Developed in Porous Acrylic Fibers}

\section{Shirou Kawasaki, Mamoru Ashida, Tomoko Kamaguchi, and Kaoru Shimamura ${ }^{*}$}

Japan Exlan Co., Ltd., Researeh \& Development Department, 3-3-1, Kanaoka- higashimachi, Okayama, 704 Japan

*Department of Applied Chemistry, Facultry of Engineering, Okayama University, Tsushima, Okayama, 700 Japan

\begin{abstract}
A new method for produsing replicas of pores in porous acrylic fibers has been developed for transmis. sion electron microscopy. The method involved filling the pores with styrene followed by its polymerization. The resulting fibers impregnated with polystyrene were microtomed into sections of thickness of ca. $70 \mathrm{~nm}$, from which acrylic part was removed by extraction with dimethyl sulfoxide. This procedure resulted in pore replicas with minimum of artifacts. Application of this method to the wet spun acrylic fibers revealed morphology of the internal pore networks which were slightly oriented along the fiber axis.
\end{abstract}

(Received November 4, 1992)

\section{1. 腥首}

高分子材料の微細構造の解析には様々な方法が用いら れている。规則構造の解析はX線，電子線などの回折現 象を利用して行われる。一方，不規則構造は〜 $1 \mu \mathrm{m} ま$ では光学影微鏡で, それより小さい桠造壮電子顕微鏡を 用いて直接形態を観察する方法が最も一般的に行われて いる。内部構造を電子影微鏡観察するためには，その微 細構造を忠実に反映した状態で観察試料作製すること が要求されるが，高分子は特有の塑性を有するために試 料作製時に人工的な形態を創り出しがちである。特に

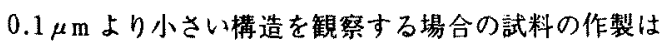
非常に難しい。そのため種々の試料作製法が提案されて いるが末解決の点が多い〔1]。

アクリル織維の湿式紡釆では凝固過程において多量の 溶媒を取り除くために多数の孔が発生する。紡出遖後の ゲル織維を凍結乾燥したものを走查型電子顕微鏡観察し た結果に基づき，凝固槽では相分離によると思われる粗 な組織が形成されると報告されている(2)。通常の織 維ではこれらの空隙は高温熱処理によってつぶされる が, 低温で後処理を行うと孔が中心部にまで発達した浅 維が作製される。本報告では，第性変形を受け易い高分
子の中に発達した微細孔の形態を直接観察することを目 的とし，一例としてこの多孔質アクリロニトル峨維を採 り上げた。この方面の研究として既に注入鋳型法が開発 されており，生物陚料の管腔臓器等の内部形態のレプリ 力の作製に遍用されている〔3〕。この方法は血管系な どの複雑な立体配置（>100 nm）を棓べるために、内 腔に半重合高分子を注入し，硬化後組織を腐食除去する というものである〔4]。本研究では，基本的にはこの 方法を適用し、孔径 $100 \mathrm{~nm}$ 以下の微細な孔のレプリカ の作製法を開発し、その結果得られた織維中の孔の形 態，配向索検討した。

\section{2. 実焕と結果}

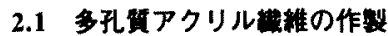

アクリロニトリル (AN) とアクリル酸メチル (MA) の共重合体（AN/MA/96/4）を約60 wt\%のロダン 酸ソ一夕 ( NaSCN) 水溶液老用いて溶解 L, 紡亲原液 を作製した。紡系原液を $5{ }^{\circ} \mathrm{C}$, 約 $12 \%$ の $\mathrm{NaSCN}$ 水溶液 中で湿式紡系を行い, さらに98 ${ }^{\circ} \mathrm{C}$ 熱水中で 5 倍延伸 した後, 得られた未乾燥暂維を $130{ }^{\circ} \mathrm{C} て ゙ 6$ 分間湿熱処理 を行い，その後60 Cで90分間乾燥した。湿熱処理によ り織維は䄪 $37 \%$ 収樎した。得られた白濁多孔質織維は, 


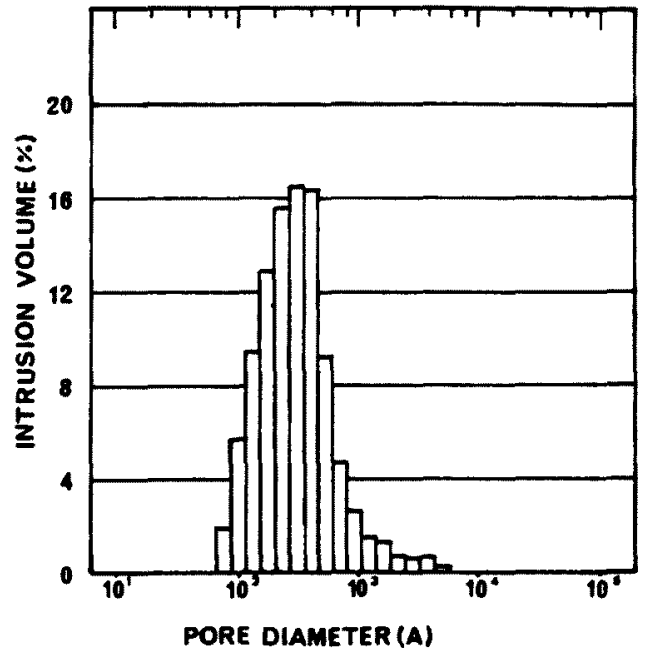

Fig. 1 Pore distribution in a porous acylic fiber.

Table 1 Embedding Matrix

\begin{tabular}{lrlr}
\hline A & \multicolumn{3}{c}{ B } \\
\hline Epok812 & $62 \mathrm{~mL}$ & Epok812 & $100 \mathrm{~mL}$ \\
DDSA & $100 \mathrm{~mL}$ & MNA & $89 \mathrm{~mL}$ \\
DMP. 30 & $1.5 \%$ & DMP 30 & $1.5 \%$ \\
\hline
\end{tabular}

(1) Epoxy resin: Epok 812

(2) Hardener: Dodecenyl succinic anhydride (DDSA) Methyl nadic anhydride (MNA)

(3) Polymerization catalyst:

2, 4,6-Dimethylaminomethyl-phenol (DMP- 30)

ジメチルフタレートにエキルアルコールを添加して屆折 率1.506（上記アクリル䄉維と同じ屈折率）に調製した 液に浸漬した結果，透明状態を示した。この緎維を $5 \times$ $10^{-2} \mathrm{mmHg}$ で脱気した後，水銀圧入法（BET法）によ り細孔经の分布を測定した結果をFig. 1 に示す [5]。

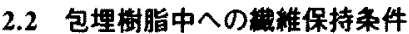

透過型電子影微鏡観祭用試料を作製するためには，緎 維（太さ約 $26 \mu \mathrm{m} ）$ を樹脂に包埋しミクロトームで約 $100 \mathrm{~nm}$ 以下の厚さの薄片に切断しなければならない。 切断に際して傤維と包埋樹脂の硬さが一致しないと䄉維 と樹脂間が制離し良質の観察試料は得られない。本奏験 では包埋用樹脂として応研商事のEpok812を用い，2つ の混合液AとBを作った（Table 1)。AとBの混合比を 変えることにより包埋用樹脂の硬さを調整できる。種々 の組成の樹脂を作り織維を包埋した試料をウルトラミク ロトーム (SORVALL 製 Porter-Blum MT- 2 UltraMicrotome) を使ってダイヤモンドナイフで厚さ約70 $\mathrm{nm}$ に切断した。包埋一切断一観察を繰り返した結果, 当アクリル䄉維の切片作製には $\mathrm{A} / \mathrm{B}=2 / 5$ が最も適 当な組成であるという結論が得られた。

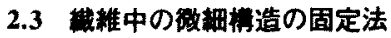

本実験で取り扱う多孔質アクリル䄉維は，通常の方法 により樹脂に包埋しただけでは，切断に際して内部の孔 の形態は変化してしまう。この孔の形状変化を防ぐため に,アクリル織維とはほ同程度の硬さの物質を孔に充填 させることが要求される。今回用いたアクリル織維のよ うに径が小さくて長い孔のレプリカを作製するために は，孔の充填操作の段階では物筫の粘度はできるだけ低 い方か望ましい。更にこの浸透操作中にアクリル瀻維を 膨潤させず，また重合は起こらず，その後加熱などの操 作で容易に重合，硬化することも要求される。このよj な条件を満たすものとしてスチレンを使用した。

栈維を $3 \mathrm{~cm}$ 程度の長さに切り，フラスコ内に入れ真空 ポンプで孔内のガスを充分脱気 $\left(3 \times 10^{-3} \mathrm{mmHg}\right.$, 約 6 時間）した。過酸化ベンゾイル（約 $2 \mathrm{wt} \%)$ を加えた スチレンを滴下, 浸漬した後, 大気圧に戻し孔内にスチ レンを浸透させたここのスチレン含浸絏維を組成比A $\mathrm{B}=2 / 5$ の包埋用樹脂で満たした容器に移した。この 包埋用樹脂はスチレンと非相溶性であるので以後の重合 過程中での織維孔内のスチレンの蒸発を防ぐ。これを70 ○の恒温槽につけスチレンの重合および包理用樹脂の硬 化を行った後，ダイモンドナイフで約 $70 \mathrm{~nm}$ の厚き に切断した。

耭維中の孔はポリスチレンで满たされているため、こ のままの状態で切片を電顕観察してもコントラストの良 い像は得られない。ポリアクリロニトリルはジメチルス ルホキシド (DMSO) に溶けるが, ポリスチレンは溶け ない。そこで、切片をカーボン膜を張ったクリッド上に 载せ, DMSO 雾国気で24時間静置しポリアクリロニトリ ルを完全に溶かし、孔の形状を写し取ったポリスチレン を得た。

\section{4 多孔留アクリル維中の孔の形態ならびに配向}

維維蟿に対して直角に切断した試料の透過型電子影微 鏡写真を Fig. 2 に示す。BET法によれば孔の大きさは $23 \mathrm{~nm}$ を心に7ー150 nmに加たて分布しているこ とになる。本観祭（䄉維軸に沿って観察）によれば現夷 の孔の形状は，円筒状で，連結した網目状の組織を形成 していることがわかる。その太さは平均70 nmである。 一方，䄉維軸に平行に切断した試料では円筒孔は平均と して轿維軸方向に配向している。孔の太さは直角方向の 孔より 10〜20 nm 細い。この戥維に対して垂直にX 線 を入射したときのX線小角散乱像を Fig４(a)に示す。 また,Fig. 4(b)は，Fid．3(a)を光学マスクとした光学変 

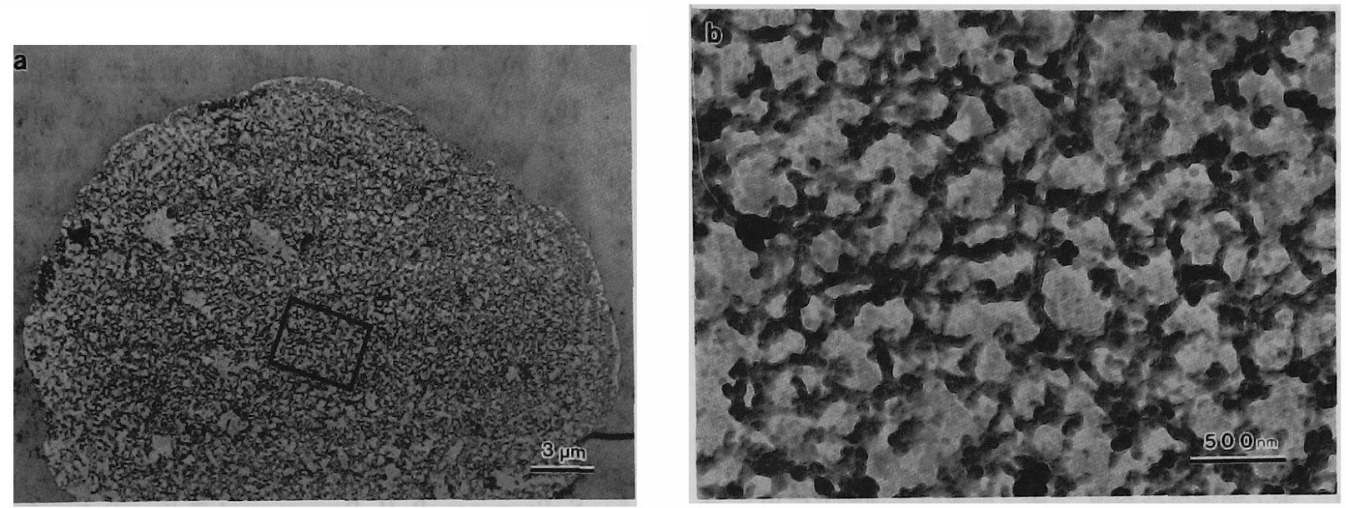

Fig. 2 Transmission electron micrographs of pore replicas distributed in a cross section of a porous acrylic fiber (Pores are replicated with polystyrene) (a) lower magnification; (b) higher magnification.
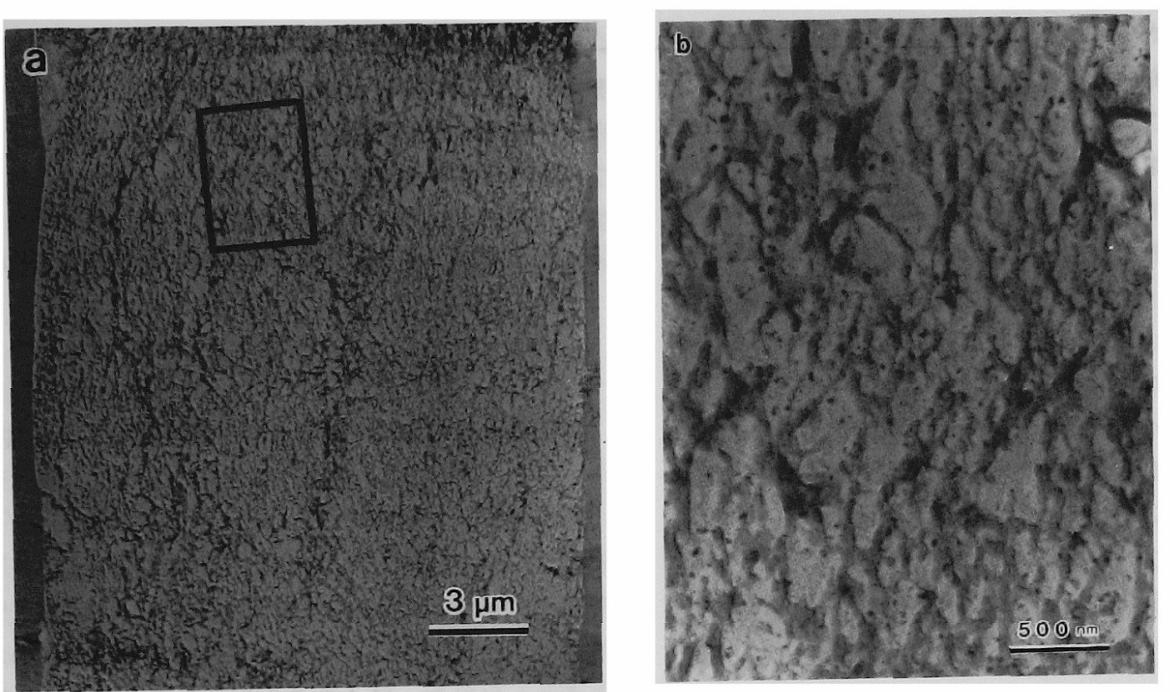

Fig. 3 Transmission electron micrographs of pore replicas distributed in a longitudinal section of a porus acrylic fiber (Pores are replicated with polystyrene) : (a)

(a) lower magnification ; (b) higher magnification.
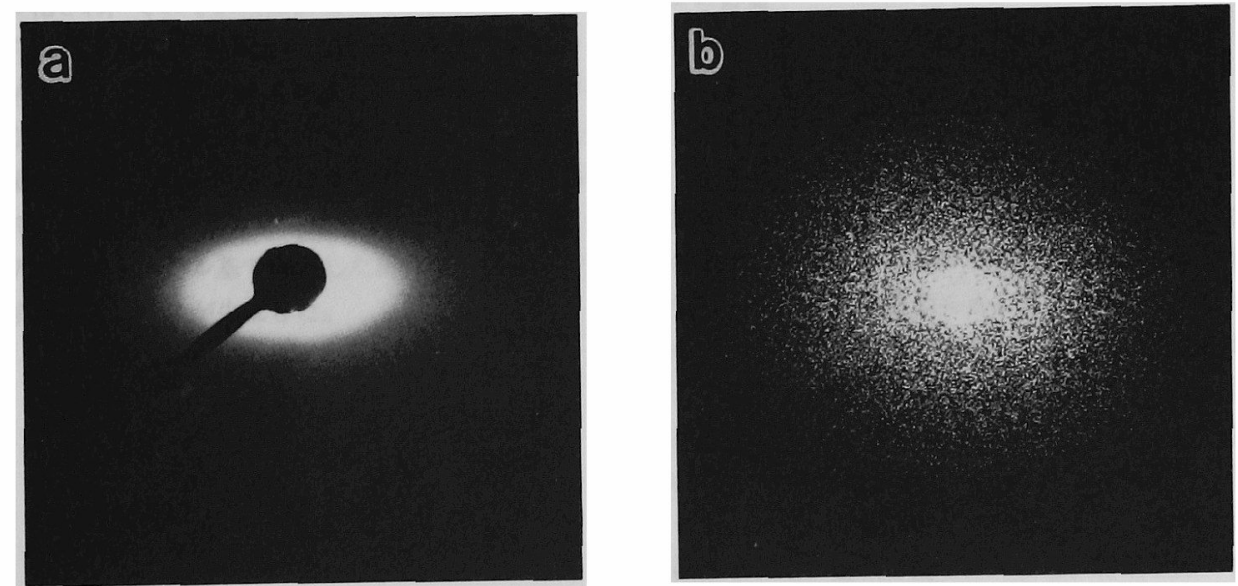

Fig. 4 (a) Samll angle X. ray diffraction of porous acrylic fibers and (b) optical transform of Fig. 3 (a). 
換像である。光学变換像とX 楾小角散乱像が類似してい ることから，このX線小角散乱像は孔の分布，配向状態 に関係していることがわかる。X線小角散乱像，および 䄉維の硬終延伸倍率 (7.9倍) から経験的に推定されて きた配向度に比べ，現実の円筒乱の配向はかなり悪いこ とがわかる。このような高分子材料中に発生した孔の形 状, 配向などの観察法の開発は湿式紡系, 延伸, 熟処理 におけるミクロな構造形成過程の追究の可能性を示唆し ている。

\section{文献}

1. 電子顕微鏡学会編, 「電子顕微鏡の理論と応用」, 丸 善, p.230 (1959).

2. J. P. Craing, J. P. Knudsen, and V. F. Holland, Tex.
Res. J., 32, 435 (1962), 竹田弘, 渡辺正元, 䄉学 誌, 19, 713 (1963), 竹田弘, 渡辺正元, 織学誌, 19, 717 (1963), 寺田弘司, 北川日出次, 加藤崖 一, 織学誌, 28, 281 (1972), 寺田弘司, 緎学誌, 28, 505 (1972), 寺田弘司, 䄉学誌, 29, T-120 (1973), 寺田弘司, 械学誌, 29, T-338 (1973), 寺田弘司, 辅学誌, 29, T-345 (1973).

3. 村上宅郎, 大谷修, 「図説走査電子顕繳鏡」(田中敬 一, 永谷隆編)，朝會書店, p133 (1980).

4. T. Murakami, Arch, Histol. Jap., 32, 445 (1971), M. L.Lee, Anat. Rec., 172, 353 (1972).

5. S. Brunauer, P. H. Emmett, and Teller, J. Am. Chem. Soc., 60, 309 (1938). 